\title{
Policy Brief
}

\section{Property Taxes: Why Some Local}

Governments Get More Than Others

\section{SUMMARY}

Some cities, counties, schools and other local governments receive more property taxes than others. The extent of this local government revenue variation is considerable, whethermeasured on the basis of dollars per resident or as a percent of property taxes collected in a community. Lately, this variation in property tax receipts has been the subject of legislative interest.

Why do some local governments receive more property tax revenues than others? Four factors account for most of this variation. Specifically, property tax revenues tend to be higher for those local governments where:

* Land is extensively developed.

* Few services are provided through special districts.

- Redevelopment is not used extensively .

* The government's property tax rate in the 1970s was relatively high.

This policy brief examines the variation in property tax receipts of local governments. It then reviews the four principal factors underlying this revenue variation, including "AB 8" (Chapter 282, Statutes of 1979)-the state law governing the distribution of property taxes. The policy brief concludes with a discussion of the concept of "equalizing" local property tax receipts. 


\section{INTRODUCTION}

California property owners pay about $\$ 19$ billion in property taxes each year. As a source of revenue, the property tax annually raises about as much as the state's income tax or the combined state and local sales tax. Unlike the income and sales taxes, however, property taxes are used exclusively for local purposes. All property taxes are allocated to local governments within the county in which thetax is collected. Specifically, property tax revenues are distributed to K-12 schools and community colleges, counties, cities, special districts, and redevelopmentagencies as shown in Figure 1.

While Figure 1 shows how property taxes are distributed statewide, there is considerable variation among communities. Some local governments receivefar more property taxes than others, regardless of whether the tax allocation is measured on the basis of dollars per resident, or as a percentage of total property taxes collected in the area. For this reason, there is currently considerable interest in the concept of "equalizing" local property tax receipts.

\section{Figure 1}

\section{Which Local Governments Receive Property Tax Revenues?}

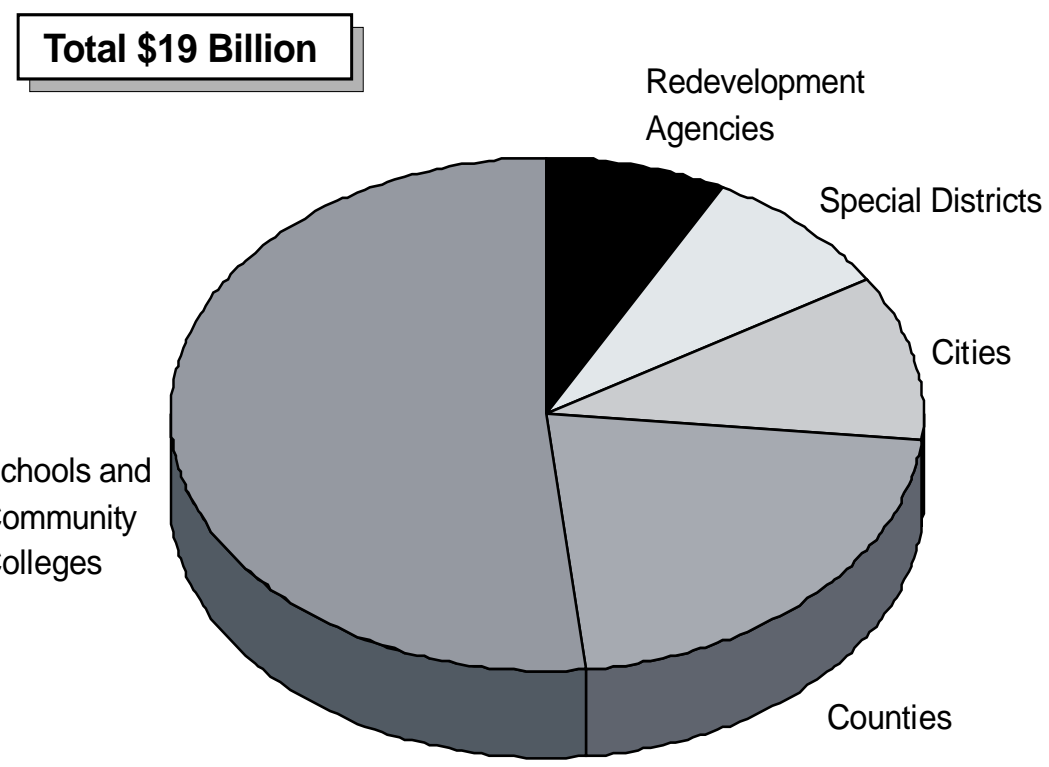

Note: Values shown are for 1994-95 and exclude debt levies. 
“. . Butte County receives about $\$ 45$ per resident, while eight counties receive more than $\$ 200$ per resident..."
This policy brief examines the variation in property tax receipts by providing information on revenues to a variety of local governments. It then discusses the four principal factors underlying this property tax variation. The policy brief concludes with a discussion of the merits of reducing the variation in property tax receipts among local governments.

\section{HOW MUCH DO LOCAL} GOVERNMENTS' PROPERTY TAX RECEIPTS VARY?

While the property tax rate and assessment practices are uniform statewide, there is considerable variation in the distribution of property taxes among local governments. Specifically, (1) the amount of property taxes and (2) the share of property taxes a local government receives differ significantly throughout the state. Counties, for example, receive between 65 percent (Alpine) and 10 percent (Yolo) of the property taxes collected within the county lines. Measured in terms of property tax revenues per resident, Butte County receives about $\$ 45$ per resident, while eight counties receive more than $\$ 200$ per resident: Alpine $(\$ 1,068)$, Amador $(\$ 208)$, Colusa (\$232), Inyo (\$394), Mono (\$537), Plumas (\$212), San Francisco (\$476), and Sierra (\$563).
As Figure 2 shows (see page 4), there is even greater variation in the amount of property taxes received by cities. While the average city receives about $\$ 75$ per resident in property taxes, some receive more than $\$ 200$ per resident and many receive less than $\$ 25$ per resident. (Cities incorporated after 1978 commonly receive very low property tax revenues for reasons discussed later in this policy brief.)

School districts also report widely different amounts of property taxes per enrolled student, ranging from around $\$ 4,000$ to less than $\$ 1,000$. The state "tops off" school district property tax revenues with state funds, however, to bring most schools to a comparable spending level for general purposes. Finally, special districts and redevelopment agencies also receive widely varying amounts of property taxes. Data limitations, however, preclude us from summarizing this variation on a statewide basis.

\section{WHY DO LOCAL GOVERNMENTS' PROPERTY}

\section{TAX RECEIPTS VARY?}

Four factors account for most of this variation in local government property tax receipts. These factors are the: 


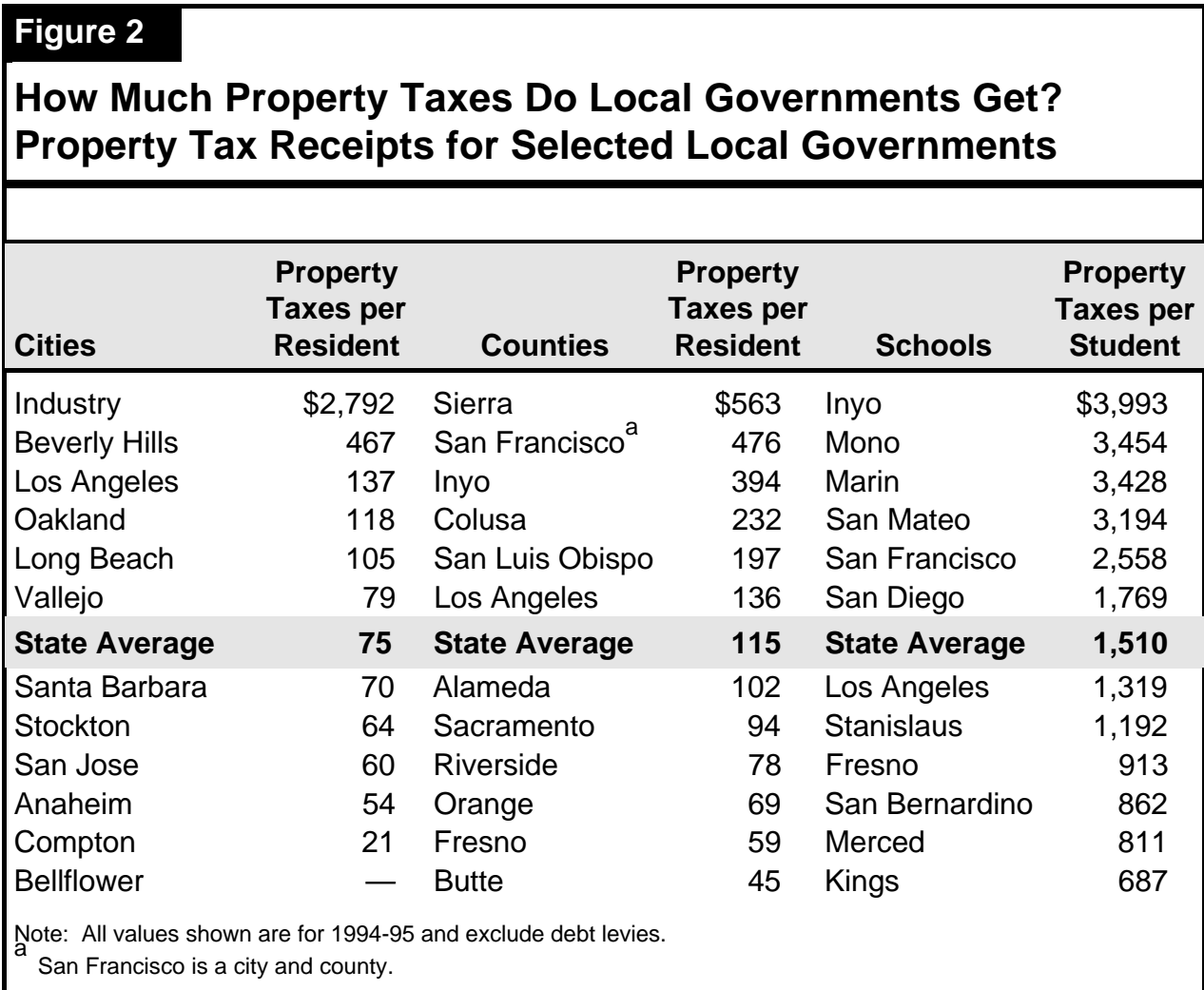

- Number and Value of Homes and Businesses in the Area. Generally, high property values yield high property tax revenues.

- Extent to Which a Local Government Provides Municipal Services. Local governments that provide a full range of municipal services-rather than relying upon special districts or other local entities-typically receive more property taxes than governments that provide fewer services.

- Extent to Which Land Is Included in a "Redevelopment" Area. Redevelopment activities may reduce property taxes to cities, counties, special districts, and schools in the area.

- State Laws Governing the Sharing of Property Taxes by Local Governments Serving a Community. Generally, the jurisdictions that had a relatively high property tax rate in the 1970s get a larger share of tax revenues today.

We discuss each factor separately below. This document also contains a detailed addendum (please see page 10) on the state laws governing the sharing of property taxes. 
". . communities

with more land

developments

[typically] require

more public

services ..."

\section{High Property Values Yield High Property Taxes}

Market forces, government infrastructure investments, natural geography, and local land use choices have acted together to create a diverse array of California communities. Some of these communities are extensively developed and have many high-value homes and businesses. Others have few land developments, or few high-value developments. These differences in the extent and value of land developments affect the amount of property taxes a community receives.

Because property taxes are levied in proportion to the assessed value of property, communities with more land developments and higher-value land developments receive more property taxes than communities with fewer developments. (Assessed value is generally the market value of a property at the time of purchase adjusted annually by a maximum of 2 percent for inflation.)

This relationship between the extent of land development and a community's property tax revenues is common throughout the United States. Typically, local communities withmoreland developments require more public services, such as streets, water systems, and police and fire protection.

\section{All Local Governments Are Not the Same}

Not all California cities, counties, and special districts have the same responsibilities. Some cities and counties provide a full array of government services, including fire protection, park and recreation programs, and water service. Other cities and counties rely upon special districts to provide some or all of these services. Statewide, for example, there are 557 special districts providing fire protection services and 293 special districts providing park and recreation services. Figure 3 (see page 6) highlights this variation in governmental responsibilities for three cities.

In addition to this variation in program responsibilities, county governments also vary in the extent to which their residents live in cities. In some counties, such as Los Angeles and Alameda, the vast majority of residents live in cities and receive some municipal services from their city government. Other counties have few or no cities-or function as both a city and a county. These counties have relatively more responsibilities.

How do these differences in responsibilities affect local government property tax receipts? If all other factors are the same, a local government providing more services generally requires more tax revenues to pay for these services. In the past, most local and state decision making 
Figure 3

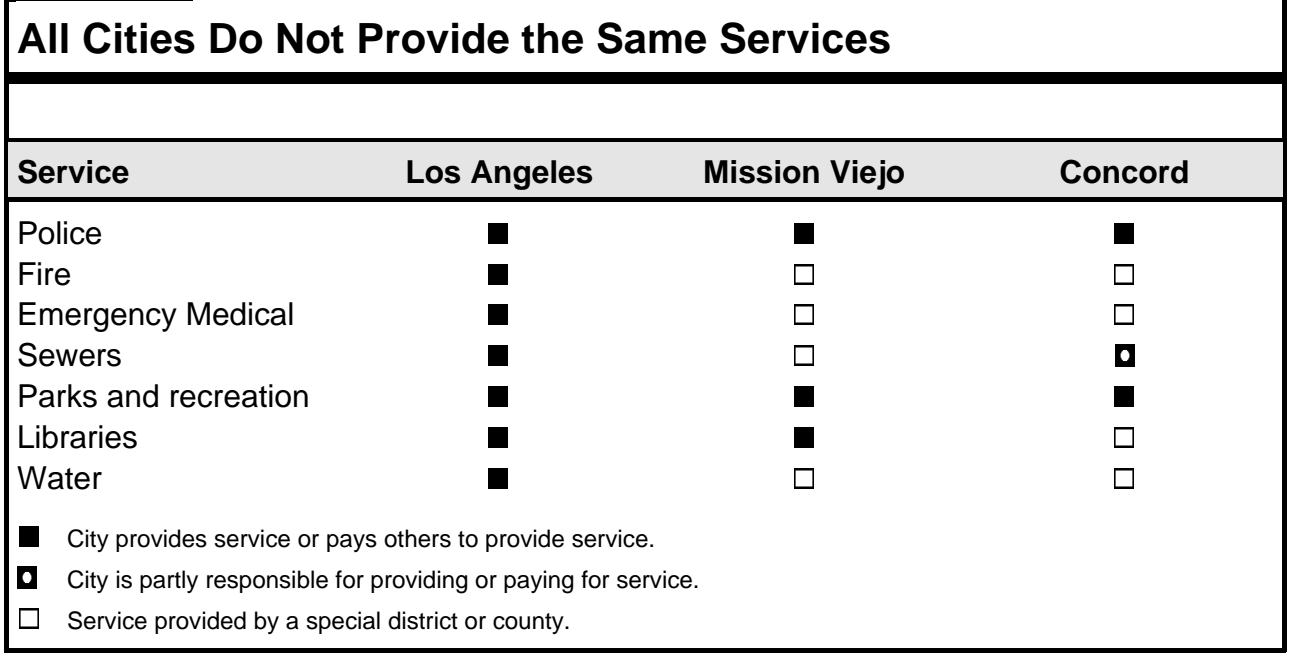

regarding theallocation of the property taxhas reflected this relationship. Thus, localgovernments withwider responsibilities typically receive more property taxes than governments with fewer responsibilities.

\section{Use of Redevelopment Influences Property Tax Receipts}

The use of redevelopment also influences the amount of property taxes local governments receive. This is because when a local government creates a "redevelopment project area," most of the growth in property taxes from this area goes to the redevelopment agency, rather than other local jurisdictions, such as the schools, county, city, and special districts.Redevelopmentagenciesuse these property tax revenues to finance improvements to revitalize the project area. After the redevelopment work is complete (typically, 30 to 40 years later), the redevelopment agency's property tax revenues are reallocated to the other local governments in the area. To date, however, only a very small percentage of all redevelopment projects have been completed.

As shown in Figure 1, nearly 8 percent, or $\$ 1.4$ billion, of property taxes is allocated to redevelopment agencies statewide. Some of these propertytaxrevenuesotherwisewould have been allocated to other local governments in the community. The use of redevelopment varies extensively throughout the state. Some cities have placed most of their developed land in redevelopment project areas. Other communities do not have any redevelopment project areas.

\section{State Determines How Property Taxes Are Shared}

Finally, the amount of property taxes allocated to local jurisdictions 
"The responsibility for allocating the property tax was assigned to the state by Proposition 13 ..." is also a function of state property tax allocation laws, principally $\mathrm{AB} 8$ (Chapter 282, Statutes of 1979). The responsibility for allocating the property tax was assigned to the state by Proposition 13 which stated that property taxes were to be allocated "according to law." Assembly Bill 8 allocated property taxes among the local governments within a county and provided fiscal relief to partially make up for property tax losses resulting from Proposition 13's tax limitation provisions.

The formulas contained in $\mathrm{AB} 8$ (for more detail see the addendum on page 10) were designed to allocate property taxes in proportion to the share of property taxes received by a local entity prior to Proposition 13. In general, each local government that provided services within a community was awarded a share of total property taxes collected within that community. Over time, as assessed values grow, the amount of property taxes received by a local government also grows. However, the share of property taxes does not change. For example, if a county, city, special district, and school district each receive 25 percent of property taxes collected within a community under $\mathrm{AB} 8$, they will continue to receive 25 percent of taxes collected regardless of how much property taxes grow. These "AB 8shares" were developed based on the historical share of property taxes received by local jurisdictions prior to Proposition 13. Local jurisdictions that had received a large share of property taxes prior to 1978 received a relatively large share of property taxes under $A B 8$. Thus, the variation in property tax receipts in effect at the time was continued.

Since 1979, as discussed in more detail in the addendum, there have been just two significant changes to the original property tax shares contained in $\mathrm{AB}$ 8: legislation designed to aid cities that receive no, or very low, property taxes and the property tax shifts of 1992-93 and 1993-94. Despite these changes, however, the state property tax allocation system developed in 1979 in response to Proposition 13 continues to be the basis for the property tax allocation among local governments.

\section{Which Factor Is Most Important?}

The four factors discussed above account for most of the variation in local government property tax receipts. Our review indicates that the relative importance of each factor differs on a community-by-community basis.

In some cases, the state's property tax allocation law-AB 8-is the major factor determining the amount of property taxes a local entity receives. Specifically, two local governments that are very similar today may receive very dissimilar amounts of property taxes because $A B 8$ 
" $A B 8$ continues

the tax sharing

ratios of the

1970s." continues the tax sharing ratios of the 1970s.

In other cases, however, the amount of local development, the reliance upon special districts, or the use of redevelopment is more determinant than $\mathrm{AB} 8$. School districts in Alpine County, for example, receive a lower share of the property taxes under AB8 than do most other school districts in the state, and school districts in Stanislaus County receive a higher share. Nevertheless, school districts in Alpine County receive nearly twice as much property taxes per student than do schools in Stanislaus County. The difference is due to AlpineCounty's high property values relative to the number of students.

Similarly, cities in Riverside County and the county itself, tend to receive relatively low amounts of property taxes per resident. These lower amounts of property taxes reflect, in part, Riverside communities' higher reliance upon redevelopment and special districts. Specifically, Riverside communities have placed large land areas under redevelopment, with the result that 19 percent of all property taxes in the county are allocated to redevelopment agencies. In addition, special districts provide some services to Riverside communities that elsewhere are provided by cities or counties.

\section{SHOULD THE LEGISLATURE EQUALIZE PROPERTY TAXES?}

Over the years, various proposals for reducing the variation in local government property tax receipts have been advanced. In considering these proposals, we recommend the Legislature first consider the causes for local government property tax revenue variation. In some cases, this variation appears to serve important policy objectives. For example:

- Allocating more property taxes to extensively developed communities helps these communities pay for services to the land developments and to the people who live and work in them. The higher tax receipts also provide an incentive for communities to promote economic development.

- Providing more property taxes to local governments with more municipalprogramresponsibilities helps the jurisdictions pay for these services.

- Allowing redevelopment agencies to keep most of the growth in property taxes in economically-distressed neighborhoods helps facilitate economic development and the eradication of urban blight. 
"Decentralization would allow the debate regarding .... local

revenues to be carried out locally, rather than in Sacramento ..."
It is less clear, on the other hand, whether property tax variation caused by the AB 8 property tax sharing methodology continues to serve important policy objectives. While this sharing methodology originally was designed to closely approximate Californian's preferences for local services, this methodology has not been updated for nearly 20 years. Since that time, California's population has grown by nearly 50 percent and the needs and preferences of local voters have surely changed. In some cases, local residents may prefer to have a special district's share of property tax revenues reduced and their city's share expanded—or the other way around.

In considering ways to update the AB 8 methodology, however, the Legislature faces major difficulties. Specifically, several thousand local governments-including over 1,000 school districts-receive a share of local property taxes. Updating the AB 8 methodology to reflect local preferences would require the Legislature to ascertain the needs and priorities of each California community and each local government. This is a task which, in our view, cannot be undertaken in a centralized manner.

For this reason, we believe that ultimately the control over allocating the property tax-or at least the nonschool portion of the property tax-should bedecentralized. Decentralization would allow the debate regarding the appropriate distribution of local revenues to be carried out locally, rather than in Sacramento, and offers Californians the best chance of aligning tax revenues with local needs and preferences. 


\section{How Property Taxes ARe Shared By Local GovernmentS: THE HISTORY OF SB 154 AND AB 8}

The current system for allocating property taxes in the state is governed to a large extent by two bills developed by the Legislature nearly 20 years ago. Following the passage of Proposition 13, the voter approved property tax limitation measure, the Legislature enacted two property tax allocation and fiscal relief bills, SB 154 (Chapter 292, Statutes of 1978) and then AB 8 (Chapter 282, Statutes of 1979). This addendum provides background information relating to the formulation of these two bills which have influenced state-local fiscal interactions for nearly two decades.

\section{Before Proposition 13-}

\section{Tax Allocation Determined Locally}

Prior to the 1978 passage of Proposition 13, each local jurisdiction authorized to levy a property tax set its own tax rate (within certain statutory restrictions). The rate set by each local government was independent of the rates set by other jurisdictions. A property owner's total property tax bill reflected the sum of the individual rates set by each taxing entity. A given piece of property might, for example, be subject to a separate tax rate for the city, county, and local school district as well as any special districts that provided services to the property.

Under this system, each local jurisdiction made a determination every year as to the amount of revenue necessary to finance the desired level of services. Based on this determination, each local entity set its property tax rate so as to collect the necessary revenue. Local residents could influence the level of both services and taxes in their community through their voting decisions. The product of this system was a set of local government services that generally reflected the individual preferences of each community in the state.

\section{Proposition 13 Required Legislature To Design New System}

Proposition 13 fundamentally changed local government finance. Property tax receipts to local governments fell by more than 50 percent as the average statewide property tax rate fell from 2.67 percent to a constitutional maximum of 1 percent. Moreover, voters required the state, rather than local government, to allocate these revenues between competing jurisdictions within a county.

\section{The First Allocation System-SB 154}

Immediately following the passage of Proposition 13, the Legislature approved SB 154 in an effort to avoid local government service diminutions and significant fiscal distress. Senate Bill 154 allocated the property taxes collected at the 1 percent rate to counties, cities, special districts, redevelopment agencies, and schools. Under SB 154, a local government's share of the property tax was based on the share of the property tax going to that local government before Proposition 13. For example, if a county government received 10 percent of the property taxes collected by all local jurisdictions in that county prior to the passage of Proposition 13, the county government would receive 10 percent of the property taxes collected at the 1 percent rate. This allocation system became the foundation of the property tax distribution mechanism subsequently enacted in $\mathrm{AB} 8$.

Senate Bill 154 also relieved counties of a portion of their obligation to pay for certain health and welfare programs and provided "bailout" block grants to partially offset the revenue loss resulting from the reduction in property tax revenues. Specifically, SB 154 provided $\$ 250$ million in block grant funds for cities and $\$ 436$ million for counties. These funds were allocated based on each local jurisdiction's property tax loss (adjusted for surplus local revenues and the value to counties of the state health and welfare "buyout") as compared to the total property tax loss for all cities and counties statewide. Special districts also received $\$ 125$ million in fiscal relief from SB 154 as well as $\$ 68$ million from related legislation. 


\section{The Current Property Tax}

\section{Allocation System-AB 8}

A year after enacting SB 154 the Legislature adopted $\mathrm{AB} 8$, a long-term policy to reallocate property taxes and provide fiscal relief to local governments. A primary objective of $\mathrm{AB} 8$ was to provide local governments with a property tax base that would increase over time as assessed value grew, thereby providing a financing mechanism for growing communities. The base property tax allocation contained in $\mathrm{AB} 8$ was essentially the same as that provided for in SB 154. However, rather than provide block grants, $\mathrm{AB} 8$ increased the share of the property taxes allocated to counties, cities, and special districts while reducing the share of the property tax going to schools. School losses were in turn made up with increased state funds for education.

The amount of the increased property tax allocation in $\mathrm{AB} 8$ was based on the block grant amount provided in SB 154. Specifically, cities received increased property taxes equivalent to 82.91 percent and special districts 95.24 percent of their SB 154 block grant amount. Under the provisions of $\mathrm{AB} 8$, counties received a combination of increased property taxes, reduced expenditure obligations, and a state block grant for indigent health programs. The major components of the expenditure reductions included complete state assumption of the costs for Medi-Cal and theStateSupplementary Program (SSP) portion of SSI/SSP, as well as an increased state share of the costs for the Aid to Families with Dependent Children (AFDC) program. In addition, AB 8 provided counties with a block grant to provide health services for the indigent. The increased share of the property tax going to counties under $\mathrm{AB} 8$ was calculated as the value of the SB 154 block grant plus a small adjustment for AFDC costs less the amount of the indigent health block grant.

What are "Negative Bailout" Counties? Under the provisions of $\mathrm{AB} 8$, six counties (Alpine, Lassen, Mariposa, Plumas, Stanislaus, and Trinity) were not awarded additional property taxes. The same calculations were applied to these counties as were applied to all others, however the value of the indigent health block grant was so great in these counties that it exceeded the value of the adjusted SB 154 block grant. (Generally, this was the case when a county had very low property tax losses from Proposition 13 and/or when a county benefitted disproportionately from the health and welfare fiscal relief components of $A B$ 8.) In order for these counties to be treated in the same way as all other counties, the amount of property taxes allocated to these counties was reduced. Because these counties received a smaller percentage of total property taxes collected after implementation of $\mathrm{AB} 8$ relative to their pre-Proposition 13 shares, these counties are termed "negative bailout counties."

\section{Two Changes to the AB 8 System}

The state property tax allocation system developed in 1979 in response to Proposition 13 continues to be the basis for the property tax allocation among local governments today. Since 1979, there have been just two significant changes to the original property tax shares contained in $\mathrm{AB} 8$. The first relates to the so-called "no and low property tax cities." Certain cities that did not levy a property tax, levied only a very low property tax, or were not incorporated as cities prior to the passage of Proposition 13 were not allocated a significant share of the property tax under $\mathrm{AB} 8$. The Legislature has acted to gradually increase the share of property taxes going to these cities.

The second significant legislative action that affected property tax allocations was the property tax shifts of 1992-93 and 1993-94. In response to severe budget deficits, the state shifted $\$ 3.6$ billion in property taxes from counties, cities, and special districts to schools. This action reduced thestate's General Fund contribution by an equivalent amount. The property taxes were shifted roughly in proportion to the benefit received by local agencies from $A B 8$. Thus, the property tax shifts did not fundamentally alter the property tax allocation system developed by the Legislature in 1979 . 
This report was prepared by Matt Newman and Marianne O'Malley, under the supervision of Mac Taylor.

To request publications call (916) 445-2375.

This report and others are available on the LAO's World Wide Web page at http://www.lao.ca.gov. The Legislative Analyst's Office is located at $925 \mathrm{~L}$ Street, Suite 1000, Sacramento, CA 95814. 